\title{
PENANGANAN PRAKTIK PENCURIAN IKAN ILLEGAL DI PERAIRAN INDONESIA
}

\author{
Osgar S. Matompo \\ Fakultas Hukum Universitas Muhammadiyah Palu \\ Jl. Jabal Nur, No. 1, Talise, Mantikulore, Kota Palu \\ E-mail : osgarsmatompo@gmail.com
}

\begin{abstract}
Indonesia became one of the country's fisheries resources that have a very large in the world. But the fisheries potential of the above can be used optimally by the nation of Indonesia, due to rampant illegal fishing practices occurred (illegal fishing) committed by a foreign-fishing that fishing in indonesia. Do not handled the problem of illegal fishing professionally by the Government makes the problem becomes complex and complicated so this condition is exploited by the fisheries from another country to do activities that violating the provisions of the legislation.
\end{abstract}

\section{Keywords; Fisheries Resources, Enforcement, Illegal Fishing}

\begin{abstract}
Abstrak
Indonesia menjadi salah satu negara yang memiliki sumber daya perikanan yang sangat besar di dunia. Namun potensi perikanan di atas tidak dapat dimanfaatkan secara optimal oleh Bangsa Indonesia, dikarenakan maraknya terjadi praktik penangkapan ikan illegal (illegal fishing) yang dilakukan oleh nelayan-nelayan asing diperairan indonesia. Tidak tertanganinya masalah penangkapan ikan illegal secara professional oleh pemerintah menjadikan masalah menjadi kompleks dan rumit sehingga kondisi ini dimanfaatkan oleh nelayan-nelayan dari Negara lain untuk melakukan kegiatan-kegiatan yang melanggar ketentuan peraturan perundang-undangan.
\end{abstract}

\section{Kata Kunci. Sumber Daya Perikanan, Penanganan. Pencurian Ikan Illegal,}

\section{A. PENDAHULUAN}

Negara Kesatuan Republik Indonesia (NKRI), dikenal sebagai Negara Archipelagik (Archipelagic State), karena merupakan wilayah kepulauan yang bertengger di sepanjang garis khatulistiwa, memiliki luas laut sebesar 5,8 $\mathrm{Juta} \mathrm{km}^{2}$ yang terdiri dari laut territorial dengan luas 0.8 juta $\mathrm{km}^{2}$, laut nusantara 2.3 juta $\mathrm{km}^{2}$ dan Zona ekonomi eksklusif 2,7 juta $\mathrm{km}^{2}$. Di samping itu Indonesia memiliki pulau sebanyak 17.480 pulau dan garis pantai 
sepanjang $95.181 \mathrm{~km}^{2}$ yang mempunyai potensi sumber kekayaan hayati laut tersimpan didalamnya ${ }^{1}$.

Dengan letak geografis Indonesia yang berada di antara Benua Asia dan Australia serta di antara Samudera Hindia dan Samudera Pasifik telah menempatkan Indonesia pada posisi strategis ditinjau dari segi ekonomi, politik, sosial budaya dan pertahanan keamanan ${ }^{2}$. Indonesia menjadi salah satu negara yang memiliki sumber daya perikanan yang sangat besar di dunia. Menurut data Departemen Kelautan dan Perikanan, sumber perikanan laut indonesia diperkirakan mencapai 6.167 .940 ton per tahunnya dengan jumlah tangkapan yang diperbolehkan di laut territorial 5 juta ton pertahunnya, dan di Zona Ekonomi Eksklusif Indonesia (ZEEI) 1,9 juta ton pertahun ${ }^{3}$.

Namun potensi perikanan di atas tidak dapat dimanfaatkan secara optimal oleh Bangsa Indonesia, dikarenakan maraknya terjadi praktik penangkapan ikan illegal (illegal fishing) yang dilakukan oleh nelayan-nelayan asing diperairan indonesia. Daerah yang menjadi titik rawan tersebut terletak di Laut Arafuru, Laut Natuna, sebelah Utara Sulawesi Utara (Samudra Pasifik), Selat Makassar, dan Barat Sumatera (Samudera Hindia). ${ }^{4}$ Menurut data Badan Pangan Dunia atau FAO mencatat, kerugian indonesia akibat penangkapan ikan secara illegal mencapai 30 triliun per tahunnya, bahkan menurut menteri Kelautan dan Perikanan Susi Pudjiastuti kerugian indonesia akibat penangkapan ikan secara illegal jauh lebih besar, mencapai US\$ 20 miliar atau Rp 240 triliun per tahunnya ${ }^{5}$.

Maraknya praktik penangkapan ikan secara illegal (illegal fishing) di perairan indonesia umumnya diakibatkan oleh permintaan terhadap ikan sangat tinggi baik untuk memenuhi kebutuhan ekspor maupun untuk memenuhi kebutuhan masyarakat. Di sisi lain, Pasal 29 ayat (2) Undang-Undang Nomor 45 Tahun 2009 tentang Perikanan disebutkan bahwa orang atau badan hukum asing itu dapat masuk ke wilayah ZEE Indonesia untuk melakukan usaha penangkapan ikan berdasarkan persetujuan internasional atau ketentuan hukum internasional yang berlaku. ${ }^{6}$

Ketentuan Pasal 29 ayat (2) Undang-Undang Nomor 45 Tahun 2009 tentang Perikanan seakan membuka jalan bagi nelayan atau badan hukum asing untuk masuk ke ZEE Indonesia untuk kemudian mengeksplorasi serta mengeksploitasi kekayaan hayati di wilayah ZEE

\footnotetext{
1 Dewan Kelautan Indonesia, Evaluasi Kebijakan Dalam Rangka Implementasi Konvensi Hukum Laut Internasional (UNCLOS 1982) di Indonesia. Departemen Kelautan dan Perikanan Sekretariat Jenderal Satuan Kerja Dewan Kelautan Indonesia tahun 2006. Hlm 6

2 Didik Heru Purnomo, Pengamanan Wilayah Laut Indonesia, Jurnal Hukum Internasional, Desember 2004, hlm 27

${ }^{3}$ Ibid, hlm 20

http://news.detik.com/read/2009/10/09/080806/1218292/471/illegal-fishing-kejahatantransnasional-yangdilupakan diakses tanggal 31 Januari 2015, seperti juga dimuat dalam paper yang ada di e-journal.uajy.ac.id

5 Detik Finance, Menteri Susi Kerugian akibat illegal fishing $R p \quad 30$ Triliun, m.detik.com/finance//read/2014/12/01/152125 di akses tanggal 31 januari 2015

${ }^{6}$ Ibid. http://news.detik.com/read/2009/10/09/080806/1218292/471/illegal-fishing-kejahatantransnasional-yangdilupakan diakses tanggal 31 Januari 2015, seperti juga dimuat dalam paper yang ada di e-journal.uajy.ac.id
} 
Indonesia, ketentuan ini merupakan salah satu bentuk penerapan aturan yang telah ditentukan dalam Konvensi Hukum Laut Tahun 1982 yang merupakan salah satu konvensi internasional yang telah diratifikasi oleh Indonesia melalui UndangUndang Nomor 17 Tahun 1985.

Dalam ketentuan Pasal 62 ayat (3) dan (4) Konvensi Hukum Laut Tahun 1982 mengharuskan negara pantai untuk memberikan hak akses kepada negara lain untuk mengeksploitasi kekayaan hayati di wilayah Zona Ekonomi Eksklusif negara pantai apabila terjadi surplus dalam hal pemanfaatan sumber daya hayati oleh negara pantai. Kapal-kapal ikan asing yang mempunyai hak akses pada zona ekonomi eksklusif suatu negara pantai harus menaati peraturan perundang-undangan negara pantai yang bersangkutan, yang dapat berisikan kewajiban-kewajiban dan persyaratan-persyaratan mengenai berbagai macam hal, seperti perizinan, imbalan keuangan, kuota, tindakan-tindakan konservasi, informasi, riset, peninjau, pendaratan tangkapan, persetujuan-persetujuan kerja sama, dan lain sebagainya ${ }^{7}$.

Sumberdaya ikan di wilayah perairan indonesia yang cukup melimpah dan beraneka ragam, bila dimanfaatkan melebihi daya dukungnya, akan terancam kelestariannya. Ancaman terhadap kelestarian sumberdaya ikan terjadi sebagai akibat dari pelaku usaha yang memanfaatan sumberdaya ikan secara tidak bertanggung jawab dan tidak sesuai dengan peraturan perundang-undangan yang berlaku ${ }^{8}$.

Tidak tertanganinya masalah penangkapan ikan illegal secara professional oleh pemerintah menjadikan masalah menjadi kompleks dan rumit sehingga kondisi ini dimanfaatkan oleh nelayan-nelayan dari Negara lain untuk melakukan kegiatan-kegiatan yang melanggar ketentuan peraturan perundang-undangan, misalnya Filipina terkenal merupakan Negara pengekspor tuna terbesar di dunia, akan tetapi 70 persen ikan tuna yang mereka ekspor tersebut berasal dari perairan indonesia. Begitupula dengan Thailand sebagai pengekspor ikan kaleng, namun banyak pihak menyakini bahwa ikannya berasai dari perairan indonesia yang ditangkap secara illegal ${ }^{9}$.

Demi menjamin terselenggaranya pengelolaan sumberdaya ikan secara optimal dan berkelanjutan perlu ditingkatkan peran pengawas di sektor perikanan dirasa sangat penting \& cukup strategis dalam rangka menunjang pembangunan di sector perikanan secara terkendali \& sesuai dengan asas pengelolaan perikanan, sehingga pembangunan dapat berjalan secara berkelanjutan (sustainable development) yang manfaatnya bisa dirasakan secara turun temurun dan lintas generasi. ${ }^{10}$

\section{B. PEMBAHASAN}

\footnotetext{
7 Albert W. Koers, Konvensi Perserikatan Bangsa-Bangsa Tentang Hukum Laut, Gadjah Mada University Press, Yogyakarta, 1994, hlm. 36

${ }^{8}$ Frans E Likadja dan Daniel P Bessie, Hukum Laut Dan Undang-Undang Perikanan, Ghalia Indonesia, Jakarta 2005, hlm 23

${ }^{9}$ www.bi.go.id. Suaka Laut dan Solusi Illegal Fishing, di akses tanggal 31 Janurari 2015

${ }^{10}$ Dikutip dari laman lontar.ui.ac.id
} 


\section{Upaya Negara Indonesia Dalam Menangani Praktik Pencurian Ikan Secara Illegal di Perairan Indonesia}

Perairan yang berada di kedaulatan dan yurisdiksi Negara Kesatuan Republik Indonesia dan Zona Ekonomi Eksklusif Indonesia serta laut lepas berdasarkan ketentuan internasional, mengandung sumber daya ikan dan lahan pembudidayaan ikan yang sangat potensial. Sebagai negara maritim, Indonesia menyimpan potensi kekayaan sumber daya kelautan yang belum dieksplorasi dan dieksploitasi secara optimal, bahkan sebagian belum diketahui potensi yang sebenarnya untuk itu perlu data yang lengkap, akurat sehingga laut sebagai sumber daya alternatif yang dapat diperhitungkan pada masa mendatang akan semakin berkembang.

Sejumlah potensi tersebut merupakan sumberdaya yang sangat potensial dikelola, untuk kesejahteraan rakyat. Seharusnya potensi laut yang besar tersebut menjadi solusi. Namun karena selama ini kita terlalu fokus kepada sumberdaya yang ada di darat, maka sumberdaya laut yang besar menjadi tersia-siakan. Keadaan inilah yang memberikan peluang kepada bangsa-bangsa lain untuk mengeksploitasi laut kita dengan leluasa yang salah satunya dengan maraknya praktikpraktik pencurian ikan secara illegal (Illegal Fishing) di perairan Indonesia. Kerugian akibat pencurain ikan illegal di perairan indonesia setiap tahun mencapai 4 millyar US\$ atau 40 triliun rupiah $^{11}$.

Dengan diundangkannya Undang-Undang Nomor 31 tahun 2004 yang kemudian diubah dengan Undang-Undang Nomor 45 tahun 2009 tentang perikanan, ini merupakan langkah positif dan merupakan landasan hukum atau aturan bagi penegak hukum dan hakim perikanan dalam memutuskan persoalan hukum yang terkait dengan pencurian ikan illegal (illegal fishing) yang dampaknya sangat merugikan Negara. Sebagaimana di laporkan oleh Departemen Kedaulatan dan Perikanan kerugian lain yang tidak bisa di nilai akibat penangkapan illegal adalah kerusakan terumbu karang akibat penangkapan ikan ikan karang dan ikan hias dengan menggunakan bahan peledak dan potasium, padahal ekosistem terumbu karang sangat penting untuk kehidupan biota laut.

Secara umum, akibat yang ditimbulkan dari pencurian ikan di wilayah perairan Indonesia adalah sebagai berikut ini $^{12}$ :

a. Hilangnya pendapatan dan penerimaan Negara

Hal ini di sebabkan karena ikan ikan hasil tangkapan di bawa dan di jual ke luar negeri sehingga retribusi dan pajak atas hasil penangkapan itu tidak dapat di pungut Pemerintah Indonesia, sehingga dapat mengurangi pendapatan negara.

b. Rusaknya lingkungan sumber daya perikanan

\footnotetext{
${ }^{11}$ Priyanto Rahardjo, Analisis Nilai Kerugian Akibat Illegal Fishing Dilaut Arafuru, Pandangan Ilmiah ini disampaikan pada Workshop on Parameters and Indicators of Habitats to be Expressed in Map of Trawl Fishing Gear Management in Arafura Sea. Kerja sama Ditjen. Perikanan Tangkap dengan Food Agriculture Organization (FAO). Royal Hotel Bogor 19 -22 Maret 2013

${ }^{12}$ Dikutip dari artikel online di laman pt.scribd.com
} 
Hal ini di sebabkan karena kapal kapal yang melakukan pencurian ikan menggunakan alat alat yang dilarang untuk menangkap ikan, seperti menggunakan trawl yang dapat merusak :

1) Terumbu karang, karena trawl dapat beroperasi sampai ke dasra perairan sehingga merusak karang karang yang berada di pasar perairan.

2) Punahnya anak anak ikan sampai dengan ukur an tertentu, sebab trawl dapat menangkap anak anak ikan sampai ukuran tertentu

c. Berkurangnya pendapatan nelayan

Hal ini disebabkan kapal kapal pencuri ikan biasanya beroperasi di daerah perairan yang di peruntukkan bagi nelayan nelayan kecil yang beroperasi di jalur I (< 6 mil) sehingga menjadi saingan bagi nelayan nelayan kecil lainnya yang beroperasi di jalur I.

d. Bertambahnya biaya operasional nelayan untuk melaut

Hal ini di sebabkan oleh karena nelayan nelayan kecil tersebut harus menangkap ke daerah penangkapan yang lebih jauh sehingga membutuhkan biaya operasioanal yang lebih besar seperti bahan bakar, konsumsi dan lain lain.

e. Konflik antar nelayan

Hal ini di sebabkan karena penafsiran otonomi daerah yang sempit seolah olah laut terkapling- kapling sehingga nelayan dari suatu daerah tidak dapat masuk ke daerah lain untuk menangkap ikan.

Berdasarkan Undang-Undang 31 tahun 2004 Jo Undang-Undang 45 tahun 2009 tentang perikanan telah mencantumkan kegiatan-kegiatan yang masuk dalam kategori pencurian ikan (iilegal fishing) sebagaimana yang penulis uraikan pada tabel dibawah ini

Tabel 1.

Pasal Dalam Undang-Undang Nomor 31 Tahun 2004 Jo Undang-Undang Nomor 45 tahun 2009 Yang Terkait Illegal Fishing

\begin{tabular}{|c|l|}
\hline Pasal & \multicolumn{1}{|c|}{ Materi Pokok } \\
\hline 7. & $\begin{array}{l}\text { Kewajiban setiap orang untuk memenuhi kewajiban sebagaimana } \\
\text { ditetapkan oleh menteri dalam pengelolaan sumber daya perikanan }\end{array}$ \\
\hline 8. & $\begin{array}{l}\text { Kewajiban setiap orang untuk memenuhi kewajiban sebagaimana } \\
\text { ditetapkan oleh menteri dalam pengelolaan sumber daya perikanan }\end{array}$ \\
\hline 9. & $\begin{array}{l}\text { Pelarangan pemilikan dan penggunaan kapal dengan alat tangkap dan/atau } \\
\text { alat bantu yang tidak sesuai dengan ukuran yang ditetapkan,tidak sesuai } \\
\text { persyaratan atau standar dan alat tangkap yang dilarang }\end{array}$ \\
\hline
\end{tabular}

${ }^{13}$ Ibid. dikutip dari laman lontar.ui.ac.id 


\begin{tabular}{|c|c|}
\hline 12. & $\begin{array}{l}\text { Pelarangan melakukan perbuatan yang mengakibatkan pencemaran/atau } \\
\text { kerusakan sumber daya ikan dan/atau lingkungan diwilayah pengelolaan } \\
\text { RI pelarangan memasukan atau mengeluarkan ikan dan/atau hasil } \\
\text { perikanan dari dan/atau ke wilayah RI tanpa sertifikasi kasehatan untuk } \\
\text { konsumsi manusia }{ }^{4}\end{array}$ \\
\hline 21 & $\begin{array}{l}\text { Pelarangan penggunaan bahan baku, bahan tambahan makanan, bahan } \\
\text { penolong dan/atau alat yang membahayakan kesehatan manusia dan/atau } \\
\text { lingkungan dalam melaksanakan penanganan dan pengelolaan ikan }{ }^{15}\end{array}$ \\
\hline 23 & $\begin{array}{l}\text { Pelarangan penggunaan bahan baku, bahan tambahan makanan, bahan } \\
\text { penolong dan/atau alat yang membahayakan kesehatan manusia }{ }^{16}\end{array}$ \\
\hline 26 & Kewajiban memiliki SIUP \\
\hline 27 & Kewajiban memiliki SIPI bagi kapal penangkap ikan \\
\hline 28 & $\begin{array}{l}\text { Kewajiban memiliki Surat Izin Kapal Pengangkat Ikan bagi kapal yang } \\
\text { mengangkut ikan }\end{array}$ \\
\hline 29 & $\begin{array}{l}\text { WNA yang melakukan usaha perikanan di wilayah perairan Indonesia, } \\
\text { kecuali untuk penangkapan ikan di ZEE Indonesia }\end{array}$ \\
\hline 36 & Hal-hal yang dipatuhi oleh kapal asing \\
\hline 37 & Persyaratan tanda pengenal perikanan \\
\hline 38 & $\begin{array}{l}\text { Tentang hal yang harus dilakukan kapal ikan berbendera asing selama } \\
\text { berada di wilayah perairan RI }\end{array}$ \\
\hline 43 & $\begin{array}{l}\text { Kewajiban kapal ikan untuk memiliki surat laik operasi dari pengawasan } \\
\text { perikanan }\end{array}$ \\
\hline
\end{tabular}

Berdasarkan tabel di atas terlihat bahwa Undang-Undang Nomor 45 tahun 2009 Jo Undang-Undang 31 tahun 2004 tentang perikanan telah memberikan aturan yang begitu ketat terhadap pengelolaan perikanan diperairan indonesia, namun pada kenyataannya banyak Pencurian ikan (illegal fishing) yang dilakukan tanpa menggunakan Surat Izin Usaha Perikanan (SIUP) \& Surat Izin Penangkapan Ikan (SIPI) sebagaimana yang diatur dalam Undang-Undang Nomor 31 Tahun 2004 tentang perikanan Pasal 93 ayat (2) yaitu :

"Setiap orang yang memiliki dan/atau mengoperasikan kapal penangkap ikan berbendera asing melakukan penangkapan ikan di wilayah pengelolaan perikanan Republik Indonesia, yang tidak memiliki Surat Izin Penangkapan

\footnotetext{
${ }^{14}$ Dikutip dari laman digilib.uin-suka.ac.id

${ }^{15}$ Ibid.

${ }^{16}$ Ibid.
} 
Ikan (SIPI) dipidan dengan pidana penjara paling lama 6 (enam) tahun dan denda paling banyak Rp. 20.000.000.000,00 (dua puluh miliar rupiah)".

Berdasarkan ketentuan di atas bahwa kapal penangkapan ikan berbendera Indonesia dan asing melakukan penangkapan ikan di dalam wilayah pengelolaan perikanan Indonesia yang tidak memiliki atau tidak dilengkapi dengan SIPI, maka akan mendapat sanksi pidana penjara paling lama 6 (enam) tahun dan denda paling banyak Rp. 20.000.000.000,00 (dua puluh miliar rupiah).

Izin perikanan merupakan alat kontrol pemerintah dalam pengelolaan sumber daya dan usaha perikanan, dengan mengeluarkan dan mengalokasikan izin perikanan, pemerintah dapat mengetahui seberapa besar sumber daya perikanan yang suda ada dikelola dan dimanfaatkan. ${ }^{17}$ Melalui izin tersebut, orang atau badan hukum diberikan hak untuk menangkap ikan dan berusaha dibidang perikanan di wilayah perairan Indonesia, meskipun dengan izizn tersebut juga mengikat kewajiban-kewajiban tertentu yang harus dipatuhi..

Sebagaimana telah disebutkan sekilas diatas, pemerintah pada dasarnya telah menentukan dua (2) jenis surat izin yang harus dimiliki oleh orang atau badan hukum untuk menjalankan usaha penangkapan ikan di wilayah Indonesia yaitu ${ }^{18}$ :

1. Surat Izin Usaha Perikanan (SIUP)

2. Surat Izin Penangkapan Ikan (SIPI) ${ }^{19}$

Surat Izin Usaha Perikanan (SIUP) adalah suatu izin tertulis yang harus dimiliki perusahaan perikanan untuk melakukan usaha perikanan di wilayah pengelolaan perikanan Indonesia dengan menggunakan sarana produksi (kapal dan alat tangkap ikan) maka usaha yang dilakukan tanpa Surat Izin Usaha Perikanan (SIUP) adalah suatu tindak pidana kejahatan dan diancam dengan hukuman penjara paling lama 8 (delapan) tahun dan hukuman denda maksimum Rp. 1.500.000.000,00 (satu miliar lima ratus juta rupiah).

Surat Izin Penangkapan Ikan (SIPI) adalah izin tertulis yang harus dimiliki oleh setiap orang yang menjalankan usaha penangkapan ikan dengan mengunakan kapal berbendera Indonesia maupun asing. Kapal berbendera Indonesia diwajibkan memiliki Surat Izin Penangkapan Ikan (SIPI) untuk menangkap ikan baik di perairan Indonesia (yang terdiri dari perairan kepulauan Indonesia, perairan pedalaman, laut territorial dan Zona Ekonomi Eksklusif).

Jika tidak memiliki Surat Izin Penangkapan Ikan (SIPI) dapat dikategorikan sebagai pidana kejahatan dan di hukum dengan pidana penjara paling lama 6 (enam) tahun dan denda paling banyak Rp. 2.000.000.000,00 (dua miliar rupiah), sementara jika kapal perikanan berbendera asing yang melakukan penangkapan ikan tanpa Surat Izin Penangkapan Ikan (SIPI) diperairan Indonesia diancam dengan hukuman penjara

${ }^{17}$ Ibid. lontar.ui.ac.id

${ }^{18}$ Ibid.

${ }^{19}$ Kerugian Negara Akibat Pencurian Nelayan Asing Di Wilayah Perairan Indonesia Mencapai 3 (tiga) trilyun pertahun, Harian Kompas terbitan tanggal 4 Juni 2012 hal. 1. 
paling lama 6 (enam) tahun dan denda paling banyak Rp. 20.000.000.000,00 (dua puluh miliar rupiah).

Pembangunan sektor kelautan pada saat ini merupakan pilihan yang strategis dalam rangka mendukung upaya pembangunan ekonomi nasional, agar tercipta landasan ekonomi yang kuat, kaidah dasar yang melandasi pembangunan ekonomi nasional terdapat dalam pembukaan Undang-Undang Dasar Negara Republik Indonesia (UUD NRI) 1945 pada alinea keempat yang berbunyi :

"Kemudian dari pada itu untuk membentuk suatu pemerintah Negara indonesia yang melindungi segenap bangsa indonesia dan seluruh tumpah darah indonesia dan untuk memajukan kesejahteraan umum, mencerdaskan kehidupan bangsa, dan ikut melaksanakan ketertiban dunia yang berdasarkan kemerdekaan, perdamaian abadi dan keadilan sosial"

Ketentuan di atas menegaskan, kewajiban Negara dan tugas pemerintah untuk melindungi segenap sumber daya alam termasuk sumber daya alam hayati untuk kebahagiaan seluruh rakyat indonesia dan segenap umat manusia. Keberadaan kapal ikan asing yang menangkap ikan secara ilegal di Indonesia telah menimbulkan kerugian yang sangat besar. Langkah penanggulangan tidak hanya mengandalkan penangkapan pelaku illegal fishing, perlu cara-cara lain yang komprehensif.

Pemerintah melalui Kementerian Kelautan dan Perikanan (KKP) mengeluarkan beberapa kebijakan untuk mencegah terjadinya praktik pencurian ikan secara illegal (illegal fishing), di antaranya adalah sebagai berikut

a. Pembentukan Satgas Pemberantasan Illegal Fishing

Satgas ini terdiri dari perwakilan sejumlah instansi yaitu KKP, Unit Kerja Presiden Bidang Pengawasan dan Pengendalian Pembangunan (UKP4), Pusat Pelaporan dan Analisis Transaksi Keuangan (PPATK), Direktorat Jenderal Bea Cukai Kementerian Keuangan, Kementerian Perhubungan, Bank Indonesia, serta Kepolisian. Satgas di antaranya mempunyai tugas memonitor penghentian sementara (moratorium) perizinan usaha perikanan tangkap, memverifikasi kapal perikanan yang pembangunannya dilakukan di luar negeri, serta menghitung kerugian negara akibat pencurian ikan.

Menurut data KKP, potensi pendapatan negara bukan pajak (PNBP) dari sektor kelautan dan perikanan yang mencapai Rp25 triliun per tahun belum termanfaatkan, dari sumber daya ikan dan nonsumber daya ikan ${ }^{20}$. Nilai potensi tersebut rencananya dibebankan kepada kapal berbendera asing di atas 30 gros ton (GT) yang beroperasi di wilayah Negara Kesatuan Republik Indonesia (NKRI). Cara ini ditempuh untuk mengembalikan uang negara yang hilang. Saat ini, dari 5.329 kapal besar bertonase di

${ }^{20}$ Koran Sindo, Strategi Menanggulangi Pencurian Ikan, http://m.koransindo.com diakses tanggal 12 mei 2015 
atas 30 GT yang beroperasi di wilayah perairan Indonesia, 20\% di antaranya kapal berbendera asing.

Selama ini setiap kapal hanya berkontribusi sebesar Rp90 juta melalui pembayaran retribusi perizinan kapal penangkapan ikan. Padahal, dalam sekali melaut, setiap kapal dapat menghasilkan ikan hingga 2.000 ton. Tentunya nilai yang diperoleh sangat besar dibandingkan nilai pendapatan negara yang disumbangkan. Jika ditotalkan, jumlah yang disumbangkan untuk PNBP hanya berkisar Rp300 miliar per tahun. Penangguhan perizinan ini dimaksudkan untuk menekan angka kerugian dari sektor kelautan dan perikanan. Sebagai informasi, setidaknya sebanyak 207 kapal sudah dibekukan izinnya.

b. Meningkatkan Sarana dan Prasarana Pengawasan

Sarana dan prasarana pengawasan merupakan faktor terpenting dalam melakukan kegiatan pengawasan. Keberadaan sarana dan prasana yang menunjang sangat diperlukan dalam pengelolaan dan pengawasan sumberdaya perikanan di perairan indonesia. Adanya sarana dan prasarana yang menunjang akan membantu terlaksananya pengawasan yang efektif dan terkendali.

Salah satu bentuk peningkatan sarana dan prasana dibidang pengawasan yang dilakukan oleh pemerintah yaitu dengan menggunakan Vessel Monitoring System (VMS) yaitu sebuah sistem monitoring kapal ikan dengan transmitor yang berfungsi untuk mengawasi proses penangkapan ikan yang dilakukan di perairan indonesia. ${ }^{21}$ Sistem kerja pengawasan VMS dilakukan di darat melalui bantuan satelit yang mengawasi kegiatan kapal penangkapan ikan yang telah terpasang transmitter. $^{22}$ Menurut Direktur Jenderal Pengawasan dan Pengendalian Sumberdaya Kelautan \& Perikanan, VMS secara statistik diklaim dapat menanggulangi sekitar 50\% masalah dari sistem penangkapan ikan yang dilakukan secara illegal ${ }^{23}$.

Disamping menggunakan alat VMS pemerintah juga meningkatkan kerjasama dan koordinasi antar instansi pemerintah yang mempunyai kewenangan di laut, yaitu Kementerian Kelautan dan Perikanan, Kementerian Perhubungan, TNI-AL, dan Polisi Perairan. Pelaksanaan pengawasan sumber daya perikanan dilakukan dengan tahapan sebagai berikut:

1) Pengawasan pada tahap pra produksi dilakukan dengan mengedepankan pencegahan (preventif) melalui penerapan SLO dan Berita Acara Hasil Pemeriksaan Kapal (HPK) Keberangkatan sebagai hasil pemeriksaan dokumen kapal.

${ }^{21}$ Ibid. digilib.uin-suka.ac.id

${ }^{22}$ Ibid.

${ }^{23}$ Yaya Mulyana, Konservasi Kawasan Perairan Indonesia Bagi Masa Depan Dunia. Direktorat Konservasi dan Tanaman Nasional Laut, Jakarta : DIrektorat Jenderal Kelautan Pesisir dan Pulau-Pulau Kecil, Departemen Kelautan dan Perikanan. 2008. Hlm 21 
2) Pengawasan pada tahap produksi dilakukan dengan cara melakukan pemantauan kapal penangkap ikan dan kapal pengangkut ikan dengan menggunakan transmitter VMS dan patroli kapal pengawas melalui verifikasi data dokumen/perizinan, alat tangkap, ukuran kapal, ABK, wilayah penangkapan, hasil tangkapan, dan aktivasi transmitter VMS.

3) Pengawasan pada tahap pasca produksi dilakukan setelah melakukan penangkapan ikan, dengan melakukan pemeriksaan kapal penangkap ikan dan kapal pengangkut ikan, serta hasil tangkapan di pelabuhan

c. Penegakan Hukum Dibidang Perikanan

Pelaksanaan penegakan hukum dibidang perikanan menjadi sangat penting dan strategis dalam rangka menunjang pembangunan perikanan secara baik dan berkelanjutan. Adanya suatu kepastian hukum merupakan sesuatu yang sangat dibutuhkan. Karena selama pelaku-pelaku pencurian ikan diperairan Indonesia hanya dikenai sanksi yang sangat ringan padahal kerugian Negara akibat pencurian ikan tersebut sangat besar.

Ketegasan aparat yang berwenang menangani keamanan dilaut sebagai aparat penegak hukum utama sangat penting agar terwujudnya keamanan dan integritas wilayah Negara Kesatuan Republik Indonesia (NKRI) serta terlindunginya sumber daya alam di laut dari berbagai bentuk gangguan keamanan dan pelanggaran hukum di wilayah perairan yurisdiksi nasional Indonesia. Perwujudan keamanan di laut pada hakikatnya memiliki dua dimensi yaitu penegakan kedaulatan dan penegakan hukum yang saling berkaitan satu dengan lainnya. ${ }^{24}$

Persepsi keamanan di laut tidak hanya masalah penegakan kedaulatan dan hukum tetapi keamanan di laut mengandung pemahaman, bahwa laut aman digunakan bagi pengguna dan bebas dari ancaman atau gangguan terhadap aktifitas penggunaan atau pemanfaatan laut, yaitu ${ }^{25}$ :

1) Laut bebas dari ancaman kekerasan, yaitu ancaman dengan menggunakan kekuatan bersenjata yang terorganisir dan memiliki kemampuan untuk menggangu serta membahayakan personel atau negara, ancaman tersebut dapat berupa pembajakan, perampokan, sabotase objek vital,peranjauan dan aksi teror.

2) Laut bebas dari ancaman navigasi, yaitu ancaman yang ditimbulkan oleh kondisi geografi dan hidrografi serta kurang memadainya sarana bantu navigasi sehingga dapat menbahayakan keselamatan pelayaran.

3) Laut bebas dari ancaman terhadap sumber daya laut, berupa pencemaran dan perusakan ekosistem laut, serta konflik pengelolaan sumber daya laut.

\footnotetext{
${ }^{24}$ Dikutip dari laman binkorpspelaut.tnial.mil.id

${ }^{25}$ Ibid. dikutip pula dalam Tedjo Edhy Purdijanto, Mengawal Perbatasan Negara Maritim, Sinar Grafika, Jakarta, 2001, hlm 27
} 
4) Laut bebas dari ancaman pelanggaran hukum, yaitu tidak dipatuhinya hukum nasional maupun Internasional yang berlaku di perairan, seperti pencurian ikan (illegal fishing), penyelundupan dan lain-lain.

Mewujudkan stabilitas keamanan di laut diperlukan upaya untuk menghadapi segala bentuk gangguan dan ancaman di laut dengan mengerahkan kekuatan dari berbagai instansi yang berwenang melaksanakan penegakan kedaulatan hukum di laut.

\section{PENUTUP}

\section{Kesimpulan}

Berdasarkan uraian diatas, maka penulis dapat menarik kesimpulan bahwa UndangUndang Nomor 45 tahun 2009 tentang Perubahan atas Undang-Undang Nomor 31 tahun 2004 tentang perikanan telah memberikan aturan yang begitu ketat terhadap pengelolaan perikanan diperairan Indonesia. Akan tetapi pada kenyataanya masih banyak Pencurian ikan (illegal fishing) yang dilakukan tanpa Surat Izin Usaha Perikanan (SIUP) dan Surat Izin Penangkapan Ikan (SIPI) yang terjadi di wilayah perairan Indonesia. Pemerintah melalui Kementerian Kelautan dan Perikanan (KKP) mengeluarkan beberapa kebijakan untuk mencegah terjadinya praktik pencurian ikan secara illegal (illegal fishing), di antaranya adalah, Pembentukan Satgas Pemberantasan Illegal Fishing, Meningkatkan Sarana dan Prasarana Pengawasan dan Penegakan Hukum Dibidang Perikanan

\section{Saran}

Adapun saran yang disampaikan Penulis yakni sebagai berikut

a. Pemerintah melalui dewan legislatif perlu segera membuat Undang-Undang mengenai pencurian ikan secara illegal (Illegal Fishing) yang spesifik mengatur masalah pencurian ikan tersebut, karena saat ini pencurian ikan masih mengacu pada Undang-Undang Nomor 31 tahun 2004 tentang Perikanan yang telah direvisi dengan Undang-Undang Nomor 45 tahun 2009 tetap tidak bisa memberantas praktik pencurian ikan secara cepat dan tepat.

b. Perlu keberanian hakim dalam menjatuhkan putusan yang paling berat yaitu pidana denda yang besar dan perampasan kapal ikan beserta isinya agar nelayan asing jera dan tidak mengulangi lagi perbuatannya yaitu mencuri ikan di Perairan Indonesia

\section{DAFTAR PUSTAKA}

\section{Buku}

Albert W. Koers, Konvensi Perserikatan Bangsa-Bangsa Tentang Hukum Laut, Gadjah Mada University Press, Yogyakarta, 1994

Akhmad Fauzi, Kebijakan Perikanan Dan Kelautan. Gramedia: Jakarta. 2007 
Abdul Hakim G Nusantara dan Benny K Harman, Analisa dan Perbandingan UndangUndang Antimonopoli: Undang-Undang Larangan Praktek Monopoli Dan Persaingan Usaha Tidak Sehat PT Elex Media Komputindo, Jakarta,1999

Dewan Kelautan Indonesia, Evaluasi Kebijakan Dalam Rangka Implementasi Konvensi Hukum Laut Internasional (UNCLOS 1982) di Indonesia. Departemen Kelautan dan Perikanan Sekretariat Jenderal Satuan Kerja Dewan Kelautan Indonesia tahun 2006

Didik Heru Purnomo, Pengamanan Wilayah Laut Indonesia, Jurnal Hukum Internasional, Desember 2004

Lili Rasyidi dan otje Salman, Rancangan Panduan Penyusunan Tesis dan Disertasi, bandung, 2003 ,

Lawrence M, Friedman, Law and Society An Introduction, New Jersey: Prentice Hall Inc, 1977

Muhammad Sabri, Evaluasi Terhadap Pengelolaan Kapal Perikanan di Zona Ekonomi Eksklusif Indonesia, Gajah Mada, Yogyakarta, 2009

Ronny Hanitijo Soemitro, Metodologi Penelitian Hukum, Ghalia Indonesia, Jakarta, 1994

Riza Damanik. Menjala ikan terkahir (sebuah fakta krisis di laut indonesia), Jakarta, WALHI, 2008

Tedjo Edhy Purdijanto, Mengawal Perbatasan Negara Maritim, Sinar Grafika, Jakarta, 2001

Yaya Mulyana, Konservasi Kawasan Perairan Indonesia Bagi Masa Depan Dunia. Direktorat Konservasi dan Tanaman Nasional Laut, Jakarta : DIrektorat Jenderal Kelautan Pesisir dan Pulau-Pulau Kecil, Departemen Kelautan dan Perikanan. 2008

\section{Jurnal dan Makalah}

Soebiyanto, Slamet, Keamanan Nasional Ditinjau dari Prespektif Tugas TNIAngkatan Laut, Majalah Patriot, 2007

Priyanto Rahardjo, Analisis Nilai Kerugian Akibat Illegal Fishing Dilaut Arafuru, Pandangan Ilmiah ini disampaikan pada Workshop on Parameters and Indicators of Habitats to be Expressed in Map of Trawl Fishing Gear Management in Arafura Sea. Kerja sama Ditjen. Perikanan Tangkap dengan Food Agriculture Organization (FAO). Royal Hotel Bogor 19 -22 Maret 2013

\section{Internet}

Tridoyo Kusumastanto, arah dan Pendayahgunaan Riset Sosial Ekonomi Perikanan Dan Kelautan. http://www.box.net/index.php?rm=box diakses tanggal 31 Januari 2015

http://news.detik.com/read/2009/10/09/080806/1218292/471/illegal-fishing-

kejahatantransnasional-yang-dilupakan diakses tanggal 31 Januari 2015

Detik Finance, Menteri Susi Kerugian akibat illegal fishing $R p \quad 30$ Triliun, m.detik.com/finance//read/2014/12/01/152125 di akses tanggal 31 januari 2015

www.bi.go.id. Suaka Laut dan Solusi Illegal Fishing, di akses tanggal 31 Janurari 2015

Jimly Asshiddiqie, Penegakan Hukum, http://www.docudesk.com diakses tanggal 10 Oktober 2014

\section{Undang-Undang}

Undang-Undang Nomor 45 Tahun 2009 Tentang Perikanan

Konvensi Hukum Laut 1982 (UNCLOS 1982) 